\title{
PENINGKATAN KEDISIPLINAN PESERTA DIDIK DALAM RANGKA PENIGKATAN MUTU PENDIDIKAN DI MTSN GRESIK
}

\author{
Moh. Nadhiful Khoir, Nur Hanifatus Sa'adah, Junaedi, \\ UIN Sunan Ampel, Surabaya - Indonesia | nurulhasanah982202@gmail.com
}

\begin{abstract}
Abstrak: Penerapan dan penanaman nilai kedisplinan dalam jiwa peserta didik merupakan salah satu bidang yang sangat penting dalam kehidupan di lingkungan sekolah lebih-lebih bisa diterapkan dalam kehidupan bermasayarakat, berbangsa, dan bernegara. Lembaga pendidikan merupakan salah satu wahana pembangunan karakter. Penanaman nilai kedisiplinan di lingkungan sekolah dapat dilakukan dengan cara memanfaatkan dan memberdayakan semua lingkungan belajar secara optimal untuk menumbuhkan jiwa atau rasa tanggung jawab peserta didik di sekolah dengan menumbuhkan rasa disiplin peserta didik. Selain itu, dengan disiplin dapat mengembangkan produktivitas peserta didik dalam proses pembelajaran. Penelitian ini menggunakan metode deskriptif dengan pendekatan kualitatif. Data dikumpulkan melalui wawancara mendalam dan observasi. Hasil penelitian menunjukkan bahwa: 1) Madrasah membentuk nilai kedisiplinan peserta didik sehingga menjadi madrasah yang bermutu. 2) kedisiplinan yang tiap hari ditingatkan, 3) Menjadikan madrasah ini menjadi madrasah yang terpandang di Gresik.
\end{abstract}

Keywords: Kedisiplinan, madrasah bermutu.

\section{Pemdahuluan}

Masalah disiplin merupakan masalah yang dihadapi sekolahsekolah dewasa ini. Disiplin merupakan suatu sikap yang menunjukkan kesediaan untuk menepati atau mematuhi ketentuan, tata tertib, nilai serta kaidah-kaidah yang berlaku. Disiplin mengandung asas taat, yaitu kemampuan untuk bersikap dan bertindak secara konsisten berdasar pada suatu nilai tertentu. Dalam proses belajar mengajar, kedisiplinan dapat menjadi alat yang bersifat preventif untuk mencegah dan menjaga hal-hal yang 
dapat mengganggu dan menghambat proses belajar. Untuk itu berbagai peratutan ikut diberlakukan di sekolah-sekolah untuk menegakkan tingkat kedisiplinan peserta didik.

Agar seorang peserta didik dapat belajar dengan baik maka ia harus bersikap disiplin, terutama disiplin dalam hal menepati jadwal pelajaran, disiplin dalam mengatasi godaan yang akan menunda waktu belajar, disiplin terhadap diri sendiri, dan disiplin dalam menjaga kondisi fisik agar selalu sehat (Sulistiyowati, 2001: 3). Peserta didik yang disiplin dalam belajar memiliki ciri-ciri sebagai berikut : Mengarahkan energi untuk belajar secara kontinu, Melakukan belajar dengan kesungguhan dan tidak membiarkan waktu luang, Patuh terhadap rambu-rambu yang diberikan guru dalam belajar, Patuh dan taat terhadap taa tertib belajar di sekolah, Menunjukkan sikap antusias dalam belajar, Mengikuti kegiatan pembelajaran di kelas dengan gairah dan partisipatif, Menyelesaikan tugas-tugas yang diberikan guru dengan baik, Tidak melakukan hal-hal yang dilarang oleh guru.

Sekolah dipahami sebagai lembaga pendidikan formal. Di tempat inilah kegiatan belajar mengajar belangsung, ilmu pengetahuan diajarkan dan proses pembentukan kepribadian anak juga berlangsung. Dengan demikian sekolah merupakan lembaga pendidikan yang sangat strategis untuk menanamkan dan mengajarkan kedisiplinan. Untuk itu disiplin harus ditanamkan sedini mungkin di sekolah dengan cara menerapkan tata tertib, meningkatkan anjuran atau perintah yang tegas, meningkatkan kebiasaan peserta didik dalam melakukan hal-hal yang baik dan bersifat tidak merugikan peserta didik sendiri dan pihak-pihak lain.

MTsN Gresik adalah salah satu lebaga pendidikan jenjang sekolah menengah yang ikut menerapkan kedisiplinan peserta didik. Sekolah ini menjadi tempat kelanjutan pembinaan kedisiplinan yang sudah dilakukan oleh keluarga peserta didik. Berbagai bentuk tata tertib serta peraturan telah ditetapkan di sekolah ini namun pada kenyataannya ketidakdisiplinan peserta didik di sekolah ini masih saja terlihat. Sedikit permasalahan yang timbul adalah masih adanya peserta didik yang melanggar tata tertib terkait penerapan kedisiplinan baru dalam rangka 
menciptakan ligkungan sekolah yang bersih, dan bermain-main di dalam kelas.

Adapun demikian juga menjadi permasalahn yang bessar yang nantinya berdampak kepada peserta didik yang lain yang mana dapat dipengaruhi oleh beberapa faktor yaitu faktor internal dan faktor eksternal. Faktor internal yaitu faktor yang berasal dari dalam diri peserta didik, terdiri atas kecerdasan, bakat, perhatian, motivasi, disiplin, kesehatan jasmani, dan cara belajar. Faktor eksternal adalah faktor yang berasal dari luar diri peserta didik terdiri dari lingkungan sekolah, peralatan sekolah, teman, keluarga, dan masyarakat.

Bagi setiap institusi yang mana dalam hal ini adalah lembaga pendidikan, mutu merupakan suatu hal yang penting dan meningkatkan mutu adalah tugas yang paling utama bagi lembaga pendidikan. Mutu pendidikan seringkali di anggap sebagai tolok ukur keberhasilan pendidikan. Jika lembaga pendidikan mampu melahirkan lulusan yang aktif, cerdas, kritis, dan dapat meneruskan pendidikan ke jenjang yang lebih baik, maka sudah dipastikan bahwa lembaga pendidikan tersebut memiliki mutu pendidikan yang baik. Begitupun sebaliknya, jika lulusan dari suatu lembaga pendidikan kurang baik, peserta didiknya seringkali dicap sebagai anak nakal maka bisa jadi mutu yang dimiliki oleh lembaga pendidikan tersebut kurang baik.

Untuk mendapatkan mutu pendidikan yang baik, sekolah harus memiliki fasilitas yang baik pula. Mulai dari sarana dan prasarana yang memadai, tenaga pendidik dan kependidikan yang bersertifikat, memiliki teknologi yang mutakhir, hingga aturan yang mendukung kebutuhan peserta didik. Adapun aturan yang diberlakukan sudah seharusnya didukung dan dilaksanakan oleh seluruh warga sekolah untuk menciptakan kedisiplinan di sekolah. Jika kedisiplinan sudah ditegakkan, maka produktivitas warga sekolah khususnya peserta didik dapat terlihat. Sehingga dapat meningkatkan mutu pendidikan yang ada di sekolah.

Berdasarkan hasil pengamatan penulis saat melakukan PMPI di MTsN Gresik, tingkat kedisiplinan peserta didik MTsN Gresik dapat dilihat sejak awal pelajaran dimulai sampai pelajaran 
berakhir. Ketertiban peserta didik MTsN Gresik dari awal masuk gerbang sampai pelaksanaan kegiatan awal, cukup megensankan, minimnya peserta didik yang terlambat dalam melaksnakan kegiatan awal, bahkan bisa dikatakan tidak ada, dan dilanjut pelakasnaan sholat duhah berjama'ah, kemudian pada saat pembelajaranpun peserta didik mudah sekali dikendalikan untuk mengikuti proses pembelajaran yang ada, pada saat istirahat peserta didik bergantian untuk megantri di kantin sampai jam masuk berbunyi, hingga saat pelaksanaan sholat duhur dan ashar juga sama, dan berlanjut sampai bel pulang dibunyikan, yang mana ini tidak lepas dari penanaman rasa tanggung jawab peserta didik yang sudah terbangun sejak awal masuk di MTsN Gresik.

Belajar adalah proses untuk memperoleh pengetahuan, keterampilan dan sikap yang menghasilkan suatu perubahan tingkah laku. Perubahan tinglah laku peserta didik di sekolah diwujudkan dalam hasil belajar yang diperolehnya dari hasil belajar itu sendiri. Hasil belajar merupakan umpan balik dari proses pembelajaran yaitu tolok ukur yang digunakan untuk menentukan keberhasilan peserta didik dalam mengetahui dan memahami suatu kompetensi. Hasil belajar adalah sesuatu yang diperoleh dari kegiatan yang telah dikerjakan, diciptakan baik secara indivvidual maupun kelompok. Hasil ini tidak diperoleh selama seseorang tidak melaksanakan kegiatan.

Guru di MTsN Gresik menjadi unsur penting dalam mewujudkan keberhasilan proses belajar mengajar di jenjang sekolah menengah ini. Guru memiliki peran aktif dalam mengendalikan berbagai perilaku yang tidak disiplin dan menanamkan kebiasaan peserta didik dengan perilaku-perilaku yang disiplin, mendidik kedisiplinan, meningkatkan anjuran atau perintah untuk mentaati berbagai peraturan serta memberi sanksi yang tegas bagi peserta didik yang melanggar kedisiplinan.

Disamping itu juga, Peraturan sekolah merupakan pedoman yang digunakan oleh peserta didik. Peraturan memiliki peranan yang penting untuk menata tingkah laku seseorang. Hal tersebut sesuai dengan pendapat Maria J. Wantah (2005: 152) yang mengatakan bahwa peraturan memiliki dua fungsi yang penting 
dalam membantu anak untuk menjadi manusia yang disiplin. Pertama, peraturan memiliki nilai pendidikan, sebab peraturan memperkenalkan kepada anak perilaku yang disetujui oleh anggota kelompok tertentu. Kedua, peraturan membantu mengekang perilaku yang tidak diinginkan. Peraturan akan dapat membantu anak untuk menyesuaikan diri terhadap peraturan untuk mencapai kedisiplinan.

Secara etimologi disiplin berasal dari bahasa latin "disibel" yang berarti pengikut. Seiring dengan perkembangan zaman, kata tersebut mengalami perubahan menjadi "disipline" yang artinya kepatuhan atau menyangkut tata tertib. Sekarang ini kata disiplin telah berkembang mengikuti kemajuan ilmu pengetahuan, sehingga banyak pengertian disiplin yang berbeda antara ahli yang satu dengan yang lain. Menurut Sulistiyowati (2001: 3) agar seorang peserta didik dapat belajar dengan baik maka ia harus bersikap disiplin, terutama disiplin dalam hal-hal sebagai berikut:

Disiplin dalam menepati jadwal pelajaran.

Bila seorang peserta didik mempunyai jadwal kegiatan belajar, ia harus menepati jadwal yang telah dibuatnya. Dalam hal ini jauh sebelumnya sudah diperintahkan untuk membuat jadwal belajar sesuai dengan jadwal pelajaran.

Disiplin dalam mengatasi godaan yang akan menunda waktu belajar. Bila seorang peserta didik sudah tiba waktunya untuk belajar kemudian diajak bermain oleh temannya, maka peserta didik tersebut harus dapat menolak ajakan temannya secara halus agar tidak tersinggung.

Disiplin terhadap diri sendiri. Peserta didik dapat menumbuhkan semangat belajar baik di sekolah maupun di rumah. Sekalipun peserta didik mempunyai rencana belajar yang baik akan tetap tinggal rencana kalau tidak adanya disiplin diri.

Disiplin dalam menjaga kondisi fisik agar selalu sehat dan fit dengan cara makan makanan yang bergizi dan berolahraga secara teratur. Disiplin dalam menjaga kondisi fisik sangat penting. Jika tidak akan mempengaruhi aktivitas sehari-hari. Misalnya seorang peserta didik sebelum berangkat sekolah harus sarapan dulu agar mendapatkan badan yang bugar, tidak lemas karena kelaparan saat 
mengikuti pelajaran, sehingga peserta didik dapat mengikuti kegiatan belajar dengan baik.

Kedisiplinan merupakan fungsi operatuf manajemen dari seluruh organisasi termasuk organisasi sekolah karena semakin baik disiplin peserta didik, maka semakin tinggi prestasi belajar yang dapat dicapai oleh mereka. Tanpa disiplin yang baik, sulit bagi peserta didik untuk mencapai hasil pembelajaran yang opimal. Disiplin adalah kepatuhan untuk menghormati dan melaksanakan suatu sitem yang mengharuskan orang untuk tunduk pada keputusan, perintah atau peraturan yang berlaku. Dengan kata lain disiplin adalah kepatuhan mentaati peraturan dan ketentuan yang telah ditetapkan. Menurut Ekosiswoyo dan Rachman (2000: 97), "disiplin hakikatnya adalah pernyataan sikap mental individu maupun masyarakat yang mencerminkan rasa ketaatan, kepatuhan, yang didukung oleh kesadaran untuk menunaikan tugas dan kewajiban dalam rangka pencapaian tujuan".

Dari uraian di atas jelaslah bahwa disiplin dalam belajar hendaknya dimiliki oleh setiap peserta didik yang akhirnya nanti bisa jadi kebiasaan, maka akan terbentuk etos belajar yang baik. Belajar bukan lagi sebagai beban melainkan sudah dianggap sebagai kebutuhan hidupnya. Disiplin yang sebenarnya mendorong anak untuk memberikan kontribusi pada kelas, teman sebaya, dan keluarga mereka (Allen, 2005: 26).

Menurut Atheva (2007: 57) orang yang disiplin memiliki ciri-ciri sebagai beriut:

- Selalu mentaati peraturan atau tata tertib yang ada.

- Selalu melaksanakan tugas dan kewajiban yang diterimanya dengan tepat waktu.

- Kehidupannya ertib dan teratur.

- Tidak mengulur-ulur waku dan menunda pekerjaan.

Berdisiplin sangat penting bagi setiap peserta didik. Berdisiplin akan membuat seorang peserta didik memiliki kecakapan mengenai cara belajar yang baik, juga merupakan suatu proses ke arah pembentukan watak yang baik.

Kedisiplinan di sekolah memiliki fungsi tertentu. Kedisiplinan sekolah berfungsi sebagai alat pendidikan dan alat menyesuaikan 
dalam membentuk sikap dan tingkah laku yang baik, yang nantinya dapat digunakan juga dalam lingkungan keluarga maupun lingkungan masyarakat. Dengan demikian kedisipinan sebagai alat pendidikan adalah suatu tindakan, perbuatan yang dengan sengaja diterapkan untuk kepentingan pendidikan di sekolah. Tindakan atau perbuatan tersebut dapat berupa perintah, nasehat, larangan, harapan, dan hukuman atau sanksi. Kedisiplinan sebagai alat pendidikan diterapkan dalam rangka proses pembentukan, pembinaan dan pengembangan sikap serta tingkah laku yang baik. Sikap dan tingkah laku yang baik tersebut dapat berupa ijin, berbudi pekerti luhur, patuh, hormat, tenggang rasa, dan berdisiplin. Tujuan disiplin adalah mengarahkan anak agar mereka belajar mengenai hal-hal baik yang merupakan persiapan bagi masa dewasa, saat mereka sangat bergantung kepada disiplin diri (Rimm, 2003: 47).

Sulistyowati (2001: 13) menyebutkan agar seorang pelajar dapat belajar dengan baik ia harus bersikap disiplin, terutama disiplin dalam hal-hal sebagai berikut:

- Disiplin dalam mencapai jadwal belajar.

- Disiplin dalam menguasai semua godaan yang akan menundanunda waktu belajar.

- Disiplin terhadap diri sendiri untuk dapat menumbuhkan kemauan dan semangat belajar baik di sekolah seperti menaati tata terbit maupun disiplin di rumah seperti teratur dalam belajar.

- Disiplin dalam menjaga kondisi fisik agar selalu sehat dan fit dengan cara makan yang teratur dan bergizi serta berolahraga secara teratur.

Kegiatan pembelajaran di sekolah tentulah melalui proses yang sangat kompleks serta dipengaruhi oleh berbagai faktor. Agar proses belajar memperoleh hasil yang baik, maka perlu diperhatikan berbagai faktor yang dapat mempengaruhi hasil belajar. Keseluruhan faktor-faktor itu saling berhubungan antara satu sama lain. Ada beberapa faktor yang mempengaruhi hasil belajar peserta didik, di antaranya yaitu faktor eksternal seperti lingkungan peserta didik, sekolah, guru, dan ekonomi keluarga. 
Sedangkan faktor dari dalam diri peserta didik seperti faktor fisiologis, faktor psikologis yang meliputi intelegensi (kecerdasan), minat, dan bakat. Semua faktor tersebut sangatlah berpengaruh terhadap baik buruknya hasil belajar peserta didik.

\section{Metodologi}

Metode yang digunakan dalam penelitian ini adalah metode deskriptif yang ditujukan untuk menggambarkan fenomenafenomena yang ada, yang berlangsung pada saat ini atau saat yang lampau. Dan juga tahap pendekatan yang digunakan dalam penelitian ini berupa pendekatan kualitatif dengan jenis penelitian deskriptif. Menurut Taylor (dalam Moleong, 2007: 4) deskriptif yaitu metode kualitatif sebagai prosedur penelitian yang menghasilkan data deskriptif berrupa kata-kata tertulis atau lisan dari orang atau perilaku yang diamati.

Penelitian ini dilakukan di MTsN Gresik. Subjek penelitian ini adalah peserta didik MTsN Gresik yang mempunyai tingkat kedispinan yang bisa dikatakan baik.

Teknik pengumpulan data yang digunakan adalah dengan menggunakan observasi, wawancara, dan dokumentasi.

Teknik analisis data yang digunakan dalam penelitian ini adalah teknik analaisis data kualitatif. Hasil pengumpulan data dengan observasi dan wawancara akan dianalisis dengan tiga tahap analisis data kualitatif di antaranya yaitu reduksi data, penyajian data dan kesimpulan.

\section{Hasil dan Pembahasan}

Penelitian melakukan observasi selama 2 bulan berada di MTsN Gresik dimulai dari minggu ketiga saat berada disana. Pada saat melakukan observasi dan pegamatan dilingkungan MTsN Gresik mulai dari proses awal peserta didik masuk sampai kembali pulang, banyak sekali hal-hal yang berbeda dibandigkan lembaga-lembaga lain yang ada di wilayah Gresik. Pertama pada saat peserta didik MTsN Gresik masuk ke dalam sekolah ketertiban mulai terlihat dihitung minimnya peserta didik yang terlambat, bahkan bisa dikatakan tidak ada peserta didik yang terlambat jika dihitung sekala tiap minggunya. Kemudian berlanjut pada agenda pertama sebelum peserta didik masuk ke dalam kelas, yaitu pada saat 
pelaksanaan shalat duhah berjama'ah, ketika informasi berkumandang di sepeker sekolah peserta didik langsung menuju ke masjid atau aula di dalam sekolah. Pun demikian kedisiplinan sangat terlihat tatkala peserta didik di MTsN Gresik melaksanakan proses pembelajaran di dalam kelas, kepatuhan terhadap ibu dan bapak guru bisa dikatakan cukup baik, dan harus mendapatkan apresiasi yang setinggi-tingginya, pun kegiatan-kegiatan berikutnya, sampai bel pulangpun berbunyi dilangit-langit madrasah.

Hal yang membuat kami terkesan tatkala ada peraturan/ tata tertib baru yang diterapkan oleh madrasah sebagi proses penunjang dalam pelaksanaan atau perwujudan menjadi lembaga yang bersih dan rapi, yang mana sudah bertahun-tahun lembaga ini mendapat peredikat madrasah Adiwiyata. Dengan perintah yang langsung di intruksikan oleh kepala madrasah yakni tentang larangan memakai sandal selain pelaksanaan sholat, yang diumumkan pada senin pagi kemudian lagsung diterapkan oleh peserta didik MTsN Gresik pada keesokan harinya, dan semuanya lansung menerapkan secara serentak dan hampir tidak ada yang melanggarnya, sesuai yang saya amati 3 minggu brikutnya selama 2 bulan berada di madrasah.

Berdasarkan hasil observasi dan wawancara dapat diketahui bahwa IR (inisial nama peserta didik) yang lahir di Banda Aceh pada tanggal 10 Oktober 10 tahun yang lalu ini memiliki sifat dan perilaku yang baik, hal ini juga dibuktikan dengan pernyataan wali kelasnya bahwa dia adalah peserta didik yang paling disiplin di kelas. Peserta didik ini termasuk anak yang pendiam dan pemalu. Dia selalu memakai seragam yang sesuai lengkap dengan bet nama dan simbol sekolah setiap hari senin hingga hari sabtu. Spserti halnya baju, IR selalu memakai sepatu berwarna hitam dan kaus kaki yang berwarna putih. Sebagai piket kebersihan kelas pada hari kamis, IR adalah peserta didik yang bertanggung jawab. Dia selalu menyapu pada hari rabu setelah semua jam pelajaran selesai. Orang tua IR selalu datang ke sekolah apabila dia berhalangan hadir. IR selalu pergi ke sekolah tepat waktu begitu pulangnya. Selain penghapus pulpen, dia membawa semua perlengkapan belajar sehingga ia jarang meminjam perlangkapan belajar kepada 
temannya. IR adalah anak yang pintar dan baik menurut wali kelas dan teman-temannya, dia selalu memperhatikan penjelasan guru saat pembelajaran dan selalu mengerjakan latihan dengan tepat waktu dan sering mendapatkan nili yang bagus. Selama pembelajaran berlangsung IR jarang ribut dan tidak suka jalan-jalan. Dia selalu meminta izin kepada guru yang mengajar ketika hendak pergi ke kamar mandi atau ketika ada keperluan yang mendesak. IR jarang menumpuk sampah dikolong meja, jika ada dia sering membuang sampah bekas makanan atau barangnya di keranjang sampah yang ada di dalam dan di luar kelasnya. Tidak seperti kebaiasaan beberapa anak lainnya, IR tidak pernah makan saat pembelajaran berlangsung. Pekerjaan rumah (tugas) biasanya dia kerjakan pada sore hari sepulang sekolah, terkadang dia mengerjakannya di balai pengajian tempat dimana dia menuntut ilmu agama.

Dengan adanya bukti peserta didik seperti IR, dapat menjelaskan bahwa kedisiplinan yang diberlakukan di Madrasah Tsanawiyah Negeri Gresik sangat diperhatikan. Madrasah sadar dengan kedisiplinan mampu membuat peserta didik menjadi pribadi yang lebih baik. Peserta didik juga dapat mengembangkan potensi yang ada pada dirinya melalui tanggung jawab terhadap tugas yang dibebankan pada dirinya. Jika sudah demikian maka madrasah telah berhasil mengarahkan peserta didiknya menuju gerbang keberhasilan. Sehingga mutu pendidikan yang ada di MTsN Gresik sudah baik karena mampu melahirkan peserta didik yang bertanggung jawab.

Mutu pendidikan tidak hanya dilihat dari kedisiplinan peserta didik melainkan dari seluruh warga madrasah. Ada banyak sumber mutu dalam pendidikan menurut Edward Sallis (2012: 31), diantaranya yaitu sarana dan prasaranaa yang memadai, guru yang terkemuka, nilai moral yang tinggi, hasil ujian yang memuaskan, dorongan dan dukungan dari orangtua, adanya kerja sama dengan instansi lain, terciptanya kepemimpinan yang baik dan efektif, perhatian terhadap peserta didik, teknologi yang mutakhir, kurikulum yang memadai, dan masih banyak yang lainnya. Alangkah baiknya jika setiap lembaga pendidikan mampu 
mewujudkan berbagai macam sumber mutu tersebut demi berlangsungnya pendidikan yang ada di Indonesia, khususnya wilayah Gresik dan sekitarnya.

\section{Kesimpulan}

Pada dasarnya disiplin merupakan sebuah kebutuhan. Karena dengan disiplin akan melahirkan perilaku-perilaku yang dapat memotivasi diri menjadi pribadi yang lebih baik. Begitu pula dengan lembaga pendidikan. Semakin baik tingkat kedisiplinan yang berlaku di sekolah, semakin baik pula kinerja kepala sekolah dalam mengorganisasikan suatu lembaga pendidikan. Sehingga jelas terlihat manajemen mutu yang ada di lembaga tersebut sudah baik.

Madrasah Tsanawiyah Negeri Gresik merupakan salah satu contoh lembaga pendidikan yang sudah menerapkan kedisiplinan pada warga madrasah terutama peserta didik, yang mana peserta didik merupakan konsumen langsung dari pendidikan itu sendiri. Hasil yang diperoleh terbukti bahwa sikap disiplin dari warga sekolah, baik peserta didik maupun tenaga pendidik sangat mempengaruhi mutu pendidikan. Cara yang dapat dilakukan untuk menanamkan sikap disiplin peserta didik antara lain menjadikan guru atau tenaga pendidik sebagai teladan yang baik bagi peserta didik di sekolah. Sekolah juga diharapkan mampu mengaplikasikan perarturan yang telah disepakati bersama agar tercipta kerja sama yang baik antar warga sekolah..

\section{References}

Allen E., Jane dan Marylin Cheryl. 2005. Disiplin Positif. Jakarta: Prestasi Putakaraya. Arikunto, Suharsimi. 2010. Prosedur Penelitian Suatu Pendekatan Praktik. Jakarta:

Rineka Cipta.

Atheva, Abi. 2007. Perilaku Baik Sehari-hari. Semarang: CV Aneka Ilmu. Ekosiswoyo, Rasdi dan Maman Rachman. 2000. Manajemen Kelas. IKIP Semarang 
Moh. Nadhiful Khoir, Nur Hanifatus Sa'adah, Junaedi,

Press

Gunarsa. 2000. Sosiologi Pendidikan. Jakarta: PT Rineka Cipta.

Imron, Ali. 2011. Manajeman Pesrta Didik Berbasis Sekolah. Jakarta: Bumi Aksara. Maria J. Wantah. (2005). Pengembangan Disiplin dan Pembentukan Moral pada Anak Usia Dini. Jakarta: Departemen Pendidikan Nasional.

Moleong, Lexy J. 2007. Metodelogi Penelitian Kualitatif. Bandung: PT Remaja Risdakarya.

Sallis, Edward. 2012. Total Quality Manajemen in Education. Jogjakarta: IRCiSoD.

Nurkancana, Wayan. 2000. Evaluasi Pendidikan. Surabaya: Usaha Nasional. Rimm, Sylvia. 2003. Mendidik dan Menerapkan Disiplin pada Anakn Prasekolah.

Jakarta/; PT Gramedia Putaka Utama.

Slameto. 2005. Belajar dan Faktor-faktor yang Mempengaruhinya. Cetakan V. Jakarta: Rineka Cipta.

Sudijono, Anas. 2010. Pengantar Statistik Pendidikan. Jakarta: Grafika Persada. Sulistiyowati, Sofchah. 2001. Cara Belajar yang Efektif dan Efisien. Pekalongan:

Cinta Ilmu.

Syah, Muhibbin. 2010. Psikologi Pendidikan. Bandung: PT Remaja Rosdakarya. 